\title{
GROWTH HORMONE TREATMENT IN CHILDREN BORN SMALL FOR GESTATIONAL AGE (SGA)
}

\author{
Aleksandra Janchevska, Marina Krstevska-Konstantinova, Velibor Tasic, Zoran Gucev
}

University Children's Hospital, Medical Faculty Skopje, Republic of Macedonia

Corresponding author: Aleksandra Janchevska, University Children's Hospital Skopje, Macedonia, Medical Faculty Skopje, Republic of Macedonia, Mother Teresa 17,1000 Skopje, Macedonia, Email: dr.sasha1969@yahoo.com

\section{ABSTRACT}

Introduction: Growth failure is a common consequence in small for gestational age (SGA) children.

Patients and Methods: The growth patterns and serum insulin like growth factor 1 (IGF1) concentrations before and after the 1st year under growth hormone treatment of 32 short stature SGA born children have been evaluated. In addition, we investigated the insulin like growth factor 1 receptor (IGF1R) exon 2 as a hotspot for IGF1R genetic alterations. It is of note that no dysmorphic features were observed in this group of children.

Results: The tests for pituitary reserve were within normal ranges for all 32 patients. Growth hormone $(\mathrm{GH})$ treatment $(0.037 \mathrm{mg} / \mathrm{kg} /$ day $)$ was initiated at the mean age of $9.32 \pm 3.19$ years. Growth velocity increased yearly from -1.80 SDS after the first year to - 0.03 SDS in the sixth year of treatment. Their IGF1 serum concentrations before treatment were age and sex appropriate, while during treatment a significant increase was observed fitting in the upper third of the normal range: before the treatment IGF1 SDS was $0.84 \pm 1.78$ after 1 st year the concentrations increased to IGF1 SDS $0.94 \pm 2.23$. No genetic alterations were found in the IGF1R exon 2 by PCR analysis.

Conclusions: Herein we present 32 short stature SGA children with no dysmorphic features treated with $\mathrm{GH}$. They all had increased growth velocity and entered the normal growth range on their growth charts. No side-effects were observed. GH treatment in children with no genetic alterations on the IGF1R exon 2 is safe and efficient in treating SGA children with short stature.

Keywords: small for gestational age, short stature, IGF1, insulin like growth factor 1 receptor, growth hormone treatment

\section{INTRODUCTION}

Children born SGA are those with birth weight and/or length $\leq 2 \mathrm{SD}$ below the mean for the gestational age (GA). [1, 2, 3, 4]

The prevalence of SGA was estimated to vary between $2.3 \%$ to $10 \%$ worldwide. In the USA, about $2.3 \%$ of all newborns were SGA [5;
2004]. A Japanese study on children born between 2006 and 2008 found the SGA prevalence to be $3.5 \%$. [6] The increasing prevalence of term newborns less than $2400 \mathrm{gr}$ was noticed in Korea, from $3.0 \%$ in 1995 to $4.6 \%$ in 2007. [7] A Swedish study reported $5.4 \%$ SGA, [8] while the highest 
observed prevalence was observed in South Asia and in Saharan countries of Africa. [9]

SGA born children have health consequences throughout their whole life. The most frequent SGA consequence is stunted growth. Although the majority of SGA born children grow fast during the first year of life, about 5-10 percent of them do not achieve catch-up growth and remain short. In premature SGA children the catch-up growth is slower and takes longer, till the 4th year of age. [7, 10] Potential risk of short stature in adulthood has been estimated to be 5-7 times higher in children born SGA than in their peers born appropriate for their gestational age, AGA. [11]

\section{PATIENTS}

We evaluated the growth patterns in the group of 32 short SGA children who underwent growth hormone $(\mathrm{GH})$ treatment.

\section{METHODS}

Clinical data included children's birth weight (BW) in kilograms, birth length (BL) in centimeters, BW standard deviation score (SDS), BL SDS and gestation weeks (GW).

Growth parameters were: height, weight, body mass index (BMI), BMI z-score, occipitofrontal circumference (OFC) and target height. The baseline was the start of the study, and in short SGA patients who were treated with GH measurements that were done every year during the follow up period. The Harpenden stadiometer, a wall mounted digital rod, was used for height measurement of the children and their parents. Weight was measured with a precision scale used exclusively for children. Patient's weight and height percentile values were assessed by plotting the measured values in WHO growth curves for the gender. The target height (TH) for boys was calculated using the formula: (paternal height + maternal height $) / 2+6 \mathrm{~cm}$ and the target height for girls as follows: (paternal height + maternal height) $/ 2$ $-6 \mathrm{~cm}$. Body mass index (BMI) was evaluated by the standard formula: $\mathrm{kg} / \mathrm{m} 2$ adequate for the patient's age and sex. The BMI stratification was: underweight $<18.5$; normal weight $=18.5-24.9$; overweight $=25-29.9$ and obese if BMI is 30 or greater. [12] In addition, we also used the BMI-z score as a more precise tool in children.

Bone age was determined according to the Greulich and Pyle standards as a standard hand and wrist radiograph. Bone maturation was expressed as the ratio between the bone age and the chronological age for a given visit. The bone age delay was calculated as chronological age minus bone age.

The serum concentrations of GH, IGF1, T4, and TSH were determined by chemiluminescence immune assay method on IMMULITE 2000 Siemens, Immunoassay System apparatus. The blood samples for IGF1 were obtained at the baseline, before the initiation of treatment, and again a year after initiation of the therapy. The insulin-like growth factor 1 binding protein 3 (IGF1 BP3) was not available.

The molecular analysis of the IGF-1R gene was performed on a "Biometra" - T3 Thermo-cycler PCR apparatus. DNA was isolated from leukocytes with a highly concentrated $5 \mathrm{M} \mathrm{NaCl}$ solution. The exon 2 was amplified with the following primers: 5'TCGACATCCGCAACGACTATC3' as the forward primer and 5'CGAAGATGACCAGGGCGTAG3' as the reverse primer. PCR products were digested with Dde I (Sygma Aldrich), and the resulting fragments were run on a $1 \%$ agarose gel and stained with ethidium bromide.

\section{Statistical analysis}

The Kolmogorov-Smirnov test (KS test) is used to check whether the values have the expected normal (Gaussian) distribution. A confidence interval $(\mathrm{CI})$ is calculated for the mean of each of the quantities. For the comparison of the IGF1 and IGF1SDS values, Fisher's test is used to check the equivalence of the variances. As the values had a size greater than 30 they were considered to be sufficiently large and a z-test was used, otherwise the standard t-test was applied. All tests had a 99\% significance, or $\alpha=0.01$.

\section{RESULTS}

Thirty-two SGA born children (M:F=17:15) had mean BW 2254.00 gr \pm 392.27 SDS and BW SDS -2.78 \pm 0.90 SDS, BL $46.87 \mathrm{~cm} \pm 2.19$ SDS and BL SDS $-1.37 \pm 0.86$ SDS and were born within $39.06 \pm 1.04$ SDS GW. Their birth parameters are summarized in Table 1. Those children did not achieve catch-up growth after the 2 nd year of age and remained short after the 4 th year and had $\mathrm{H}$ 
SDS $-2.77 \pm 0.72$ SDS, and W SDS $(-1.84 \pm 0.83$ SDS), BMI $15.44 \mathrm{~kg} / \mathrm{m}^{2} \pm 2.01 \mathrm{SDS}$, BMI z-score $(-0.97 \pm 2.03$ SDS $)$ OFC SDS $(-0.86 \pm 1.27$ SDS $)$ and TH SDS (1.16 \pm 0.76 SDS). Their auxologic values are summarized in Table 2.

Table 1. Birth parameters: Birth weight (BW), $B W S D S$, birth length (BL), BL SDS and Gestation Week $(G W)$ in a group of 32 short $S G A$ born children.

\begin{tabular}{|c|c|c|}
\hline PARAMETERS & GROUP & $\begin{array}{c}\text { short SGA } \\
\text { children } \\
\text { mean }\end{array}$ \\
\hline BW & gr & $2254.00 \pm 392.27$ SDS \\
\hline BW SDS & - & $-2.78 \pm 0.90$ SDS \\
\hline BL & cm & $46.87 \pm 2.19$ SDS \\
\hline BL SDS & - & $-1.37 \pm 0.86$ SDS \\
GW & w & $39.06 \pm 1.04$ SDS \\
\hline Patients & M & $\mathrm{n}=17$ \\
\hline & F & $\mathrm{n}=15$ \\
\hline
\end{tabular}

Table 2. Auxologic parameters: height SDS (H SDS), weight SDS (W SDS), BMI and BMI z-score, OFC SDS, target height (TH) SDS in a group of 32 short SGA born children..

\begin{tabular}{|c|c|c|}
\hline & GROUP & $\begin{array}{l}\text { short SGA } \\
\text { children }\end{array}$ \\
\hline PARAMETERS & & mean \\
\hline H SDS & - & $-2.77 \pm 0.72$ SDS \\
\hline w SDS & - & $-1.84 \pm 0.83$ SDS \\
\hline BMI & $\mathrm{kg} / \mathrm{m}^{2}$ & $15.44 \pm 2.01 \mathrm{SDS}$ \\
\hline BMI z-score & - & $-0.97 \pm 2.03 \mathrm{SDS}$ \\
\hline OFC SDS & - & $-0.86 \pm 1.27$ SDS \\
\hline TH SDS & - & $-1.16 \pm 0.76$ SDS \\
\hline
\end{tabular}

The mean bone age delay was $2.77 \pm 0.47$ SDS years.

The tests for pituitary reserve for the evaluation of $\mathrm{GH}$ reserve were done with L-Dopa and/or Clonidine. T4 and TSH serum concentrations were within normal ranges. The IGF1 serum concentrations and IGF1 SDS values in the whole group have increased significantly $(p=0.00016)$ and $(p=0.00036)$ after one year of treatment: IGF1 SDS were 0.94 \pm 2.23 .

GH treatment was initiated in all subjects with a $0.037 \mathrm{mg} /$ daily dose [13] and at an average age of $9.32 \pm 3.19$ years for $1-6.5$ years at the time of the study. The height velocity significantly increased in all subjects (Fig. 1). At the start of the GH treatment their mean height SDS was -2.77 SDS, and after the first year of treatment height velocity was increased to $8.65 \mathrm{~cm}$, lowering the mean height SDS to -1.80 SDS. The trend continued in the 2 nd year with $\mathrm{HV}$ of $7.45 \mathrm{~cm}$ (mean height SDS -1.50), and in every year consecutively. The 3rd year HV was 6.11 $\mathrm{cm}$ (mean height SDS -1.20 SDS), the 4th year $\mathrm{HV}$ was $6.73 \mathrm{~cm}$ (mean height SDS -0.47 SDS), the 5 th year HV was $7.16 \mathrm{~cm}$ (mean height SDS -0.35 SDS) and after the 6th year HV was 7.42 $\mathrm{cm}$ (mean height SDS -0.03 SDS).

The PCR amplification of the exon 2 of the IGF1R gene did not show any genetic alterations.

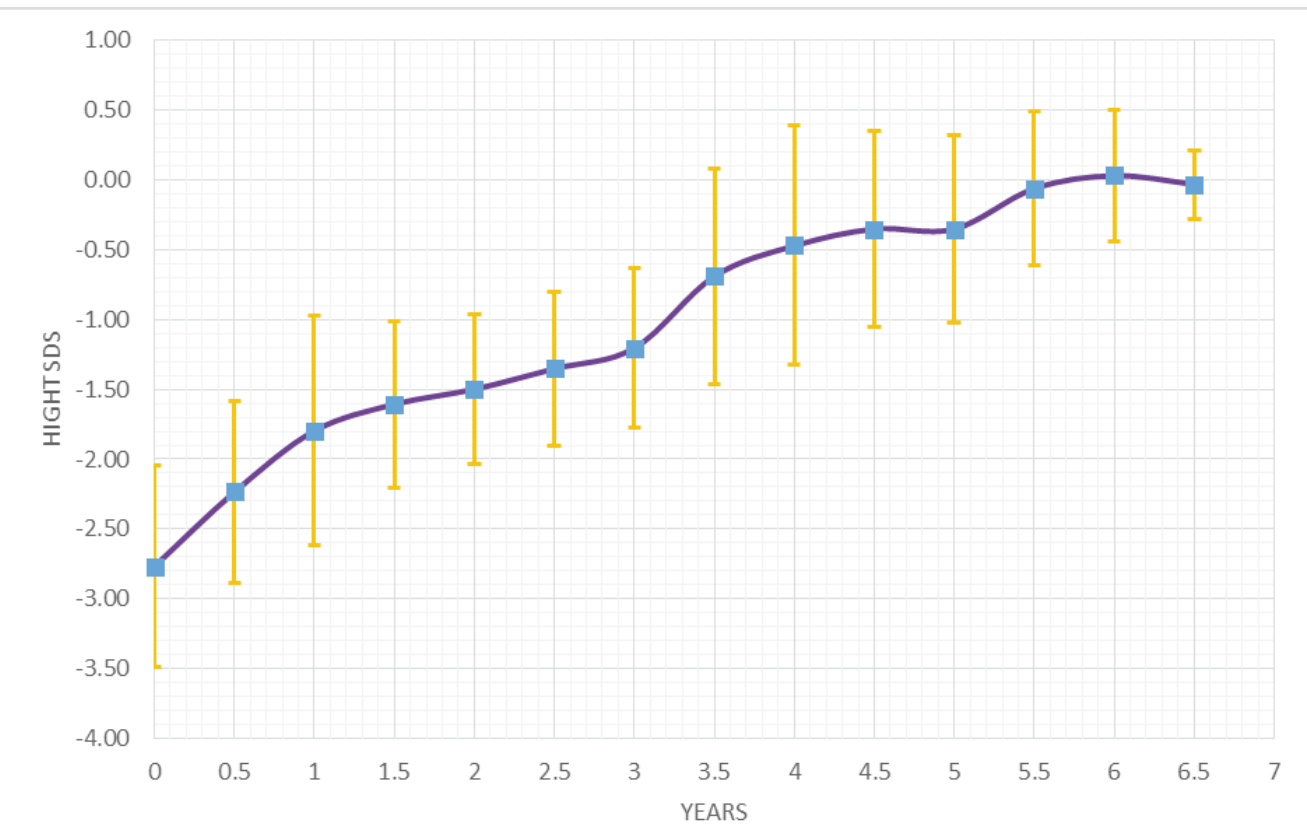

Figure 1. Growth assesment in GH treated SGA born children - height SDS 


\section{DISCUSSION}

Approximately $8 \%$ of all SGA born children have had at least minus two SDS in the final height. Most of children born SGA are not growth hormone (GH) deficient. [14, 15] Nevertheless, GH treatment for SGA children has been approved in USA and EU, starting at the age of 2 years (FDA) or four years (EMEA). [13]

By treating 32 SGA children, we also demonstrated a strongly increased growth velocity in all subjects. Moreover, they got to the point of less than two SDS of their height, and attained normal height

Schwarz et al 2014 [16] have shown gain in the mean height SDS from -3.39 SDS at start to $-2.57 \mathrm{SDS}$ and $8.99 \mathrm{~cm}$ height velocity after 1 year of treatment. Lee et al. [17] in their comparative study have shown 1.03 SDS increment in height in pre-pubertal SGA born children after 2 years of GH treatment which was greater than in children with idiopathic short stature $(+0.84$ SDS) and children with isolated growth hormone deficiency $(+0.97$ SDS). The evaluation study performed by Takeda et al. [18] has shown $4 \mathrm{~cm}$ higher adult height and significant improvement in height SDS in SGA born children who underwent GH treatment when compared to the untreated SGA born peers.

Time of onset of the GH treatment before puberty is a very important predictor for the height achievement. In fact, a start of treatment even 1 year before puberty is beneficial, but greater effect has been achieved if treatment was initiated two years before puberty. [19] If children have been treated during puberty the estimated height gain was only 0.6 SDS and less than half of them achieved favorable final adult height. [19] Favorable effects on height, height velocity and BMI was also reported by Aurensanz Clemente et al. 2017. [20]

There is a trend in treating SGA children at a younger age. Although a prevalent criteria for growth hormone treatment is age less than two years and short stature $(<-2.0 \mathrm{SD})$ and a growth velocity $<25$ th percentile for their age [21], the discussions on the appropriate age of onset of treatment abound.

In 2007, [2] Clayton et al. in their consensus statement proposed an early initiation with GH treatment in SGA children with severe growth retardation $(<-2.5$ SDS) aged between
2 and 4 years. In the very young SGA children (19-29 months) treated with GH there was a significant increment in height velocity, when compared with their untreated peers. [22] However, not all report a favourable outcome after $\mathrm{GH}$ treatment in SGA children. Tauber [23] found a mean adult height that is higher than -2 SDS in $60 \%$ of patients and $70 \%$ reached an adult height in their target height.

Having in mind the important role of growth hormone and IGF1 on brain development and linear growth, Laron et al. [24] proposed GH commencement before 2 year of age. On the other hand, the safeness and effectiveness of $\mathrm{GH}$ treatment in SGA children was also proven by decreasing the frequency metabolic complications further in adolescence and adulthood. [25] Therefore, a multidisciplinary approach (perinatologist, nutritionist and pediatric endocrinologist) is needed in the treatment and follow up of SGA born children. [21]

In our group of 32 SGA children the serum concentrations of IGF1 were within age and sex appropriate values. However, under treatment with $\mathrm{GH}$, those values increased as a group, providing a useful tool for monitoring the adequacy of GH doses. It has been demonstrated that serum IGF1 concentrations is a very important predicting parameter for the safety and effectiveness of growth hormone treatment in children. [26, 27] SGA born children had 90\% increment of IGF1 serum concentrations after the first year and 123\% after the second year of GH treatment. [28]

A number of SGA children have been found to have genetic alterations in the IGF1R gene. The exon 2 in IGF1R gene was described as a hot spot for possible alterations in SGA born children since 2003 by Abuzzahab et al. [29] Interestingly, some of those children had microcephaly and dysmorphic features. In a child with deletion on 15q26.2 intrauterine growth retardation, postnatal growth failure, and recurrent hypoglycemia were reported and a FISH study using IGF1R probes showed only a single IGF1R gene. [30] The R59X mutation was reported in two half-brothers with primary microcephaly, mild mental retardation, and intrauterine as well as postnatal growth deficits. [31] In addition, among 50 children with short stature with elevated circulating IGF1 concentrations, a R59X mutation was reported. [29] SGA, microcephaly, persistent postnatal growth retardation, and elevated IGF1 levels were reported in a 15-year-old girl with heterozygous deletion 
of 15q26.2-qter, including the IGF1R gene. [32] Microcephaly, pre- and postnatal growth retardation were found in patients with heterozygous missense mutations in three unrelated patients, de novo p.Arg1256Ser, de novo p.Asn359Tyr and p.Tyr865Cys. [33]

We checked the exon 2 of the IGF1R gene for possible genetic alterations and found no alterations.

\section{CONCLUSIONS}

We described 32 short stature SGA children with no dysmorphic features treated with GH. They all had increased growth velocity and entered the normal growth range on their growth charts. The IGF1 serum concentrations were within normal age and sex range and increased significantly during the $\mathrm{GH}$ treatment. No side-effects were observed. GH treatment in children with no genetic alterations on the IGF1R exon 2 is safe and efficient in treating SGA children with short stature.

\section{REFERENCES}

1. Saenger P, Czernichow P, Hughes I, Reiter EO: Small for gestational age: short stature and beyond. Endocr Rev 2007; 28(2): 219-251.

2. Clayton PE, Cianfarani S, Czernichow P, Johannsson G, Rappaport R, Rogol A: Management of the child born small for gestational age through to adulthood: a con-sensus statement of the International Societies of Paediatric Endocrinology and the Growth Hormone Research Society. J Clin Endocrinol Metab 2007; 92(3): 804-810.

3. Lee PA, Chernausek SD, Hokken-Koelega AC, Czernichow P: International Small for Gestational Age Advisory Board consensus development conference statement: management of short children born small for gestational age, April 24-October 1, 2001. Paediatrics 2003; 111(6 Pt 1): 1253-1261.

4. Jancevska A, Tasic V, Damcevski N, Danilovski D, Jovanovska V, Gucev Z. Children born small for gestational age (SGA). Prilozi 2012; 33(2): 47-58
5. Hamilton BE, Martin JA, Ventura SJ, Sutton BD, Menacker F. Biths: preliminary data for 2004 . Natl Vital Stat Rep 2005; 54: 1-17.

6. Fujita K, Nagasaka M, Iwatani S, Koda T, Kurokawa D, Yamana K, Nishida K, Tanigu-chi-Ikeda M, Uchino E, Shirai C, Iijima K, Morioka I. Prevalence of small for gestate-onal age (SGA) infants and short children born SGA who qualify for growth hormone treatment at 3 years of age: A population-based study. Pediatr Int. 2015 Nov 30.

7. Hwang IT. Efficacy and safety of growth hormone treatment for children born small for gestational age. Korean J Pediatr. 2014; 57(9): 379-383.

8. Albertsson-Wikland K, Karlberg J. Natural growth in children born small for gestate-onal age with and without catch-up growth. Acta Paediatr Suppl 1994; 399: 64-70.

9. Black RE. Global Prevalence of Small for Gestational Age Births. Nestle Nutr Inst Workshop Ser. 2015; 81: 1-7.

10. Argente J, Mehls O, Barrios V. Growth and body composition in very young SGA children. Pediatr Nephrol 2010; 25(4): 679-685.

11. Albertsson-Wikland K, Boguszewski M, Karlberg J. Children born small-for-gestational age: postnatal growth and hormonal status. Horm Res. 1998; 49 Suppl 2: 7-13.

12. González-Muniesa P, Mártinez-González MA, Hu FB, Després JP, Matsuzawa Y, Loos RJF et al. Obesity. Nat Rev Dis Primers 2017; 15 (3): 1-18.

13. Blankenstein O, Snajderova M, Blair J, Pournara E, PedersenBT, Petit IO. Real-life GH dosing patterns in children with GHD, TS or born SGA: a report from the NordiNet ${ }^{\circledR}$ International Outcome Study. Eur J Endocrinol. 2017; 177(2): 145-155.

14. Jung H, Rosilio M, Blum WF, Drop SL. Growth hormone treatment for short stature in children born small for gestational age. Adv Ther 2008; 25(10): 951-78.

15. Azcona C, Albanese A, Bareille P, Stanhope $\mathrm{R}$. Growth hormone treatment in growth hormone-sufficient and -insufficient children with intrauterine growth retardation/Russell-Silver syndrome. Horm Res 1998; 50(1): 22-27.

16. Schwarz HP, Birkholz-Walerzak D, Szalecki M, Walczak M, Galesanu C, Metreveli D. et al. OneYear Data from a Long-Term Phase IV Study of Recombinant Human Growth Hormone in Short Children Born Small for Gestational Age. Biol Ther. 2014 Jan 28.

17. Lee PA, Sävendahl L, Oliver I, Tauber M, Blankenstein $\mathrm{O}$, Ross $\mathrm{J}$ et al. Comparison of response to 2-years' growth hormone treatment in children 
with isolated growth hormone deficiency, born small for gestational age, idiopathic short stature, or multiple pituitary hormone deficiency: combined results from two large observational studies. Int J Pediatr Endocrinol 2012; 2012(1): 22.

18. Takeda A, Cooper K, Bird A, Baxter L, Frampton GK, Gospodarevskaya E, Welch K, Bryant J. Recombinant human growth hormone for the treatment of growth disorders in children: a systematic review and economic evaluation. Health Technol Assess 2010; 14(42): 1-209.

19. Luo ZC, Albertsson-Wikland K, Karlberg J. Length and body mass index at birth and target height influences on patterns of postnatal growth in children born small for gestational age. Paediatrics. 1998; 102(6): E72.

20. Aurensanz Clemente E, Samper Villagrasa P, Ayerza Casas A, Ruiz Frontera P, Bueno Lozano O, Moreno Aznar LA et al. Effects of growth hormone treatment on anthropometrics, metabolic risk, and body composition variables in small for gestational age patients. An Pediatr (Barc). 2017; 86(5): 240-248.

21. Boguszewski MC, Mericq V, Bergada I, Damiani D, Belgorosky A, Gunczler P et al. Latin American consensus: children born small for gestational age. BMC Pediatr 2011; 11: 66.

22. De Schepper J, Vanderfaeillie J, Mullis PE, Rooman R, Robertson A, Dilleen M, Gomez R, Wollmann HA. A 2-year multicentre, open-label, randomized, controlled study of growth hormone (Genotropin ( ()$)$ ) treatment in very young children born small for gestational age: Early Growth and Neurodevelopment (EGN) Study. Clin Endocrinol (Oxf). 2016; 84(3): 353-60.

23. Tauber M. Final height and intrauterine growth retardation. Ann Endocrinol (Paris) 2017; 78(2): 96-97.

24. Laron Z, Laron-Kenet T, Klinger G. For Debate: Growth Hormone Treatment of Infants Born Small for Gestational Age should be started at or before the First Year of Age. Pediatr Endocrinol Rev. 2016; 14(2): 105-108.

25. Zanelli SA, Rogol AD. Short children born small for gestational age outcomes in the era of growth hormone therapy. Growth Horm IGF Res. 2018; 38: 8-13.

26. Yüksel B, Özbek MN, Mungan NÖ, Darendeliler F, Budan B, Bideci A et al. Serum IGF-1 and IG-
FBP-3 levels in healthy children between 0 and 6 years of age. J Clin Res Pediatr Endocrinol. 2011; 3(2): 84-8.

27. Ranke MB, Traunecker R, Martin DD, Schweizer R, Schwarze CP, Wollmann HA, et al. IGF-I and IGF binding protein-3 levels during initial $\mathrm{GH}$ dosage step-up are indicators of GH sensitivity in GH-deficient children and short children born small for gestational age. Horm Res 2005; 64(2): 68-76.

28. Boguszewski M, Jansson C, Rosberg S, Albertsson-Wikland $\mathrm{K}$. Changes in serum insulin-like growth factor I (IGF-I) and IGF-binding protein-3 levels during growth hormone treatment in prepubertal short children born small for gestational age. J Clin Endocrinol Metab 1996; 81(11): 3902-3908.

29. Abuzzahab MJ, Schneider A, Goddard A, Grigorescu F, Lautier C, Keller E, et al. IGF-I receptor mutations resulting in postnatal growth retardation intrauterine and. N Engl J Med 2003; 349 (23): 2211-22.

30. Okubo Y, Siddle K, Firth H, O'Rahilly S, Wilson LC, Willatt L et al. Cell proliferation activities on skin fibroblasts from a short child with absence of one copy of the type 1 insulin-like growth factor receptor (IGF1R) gene and a tall child with three copies of the IGF1R gene. J Clin Endocrinol Metab 2003; 88: 5981-5988.

31. Raile K, Klammt J, Schneider A, Keller A, Laue $\mathrm{S}$, Smith $\mathrm{R}$ et al. Clinical and functional characteristics of the human Arg59Ter insulin-like growth factor i receptor (IGF1R) mutation: implications for a gene dosage effect of the human IGF1R. J Clin Endocrinol Metab 2006; 91: 22642271.

32. Walenkamp MJ, de Muinck Keizer-Schrama SM, de Mos M, Kalf ME, van Duyvenvoorde HA, Boot AM et al. Successful long-term growth hormone therapy in a girl with haploinsufficiency of the insulin-like growth factor-I receptor due to a terminal $15 \mathrm{q} 26.2->$ qter deletion detected by multiplex ligation probe amplification. J Clin Endocrinol Metab 2008; 93: 2421-2425.

33. Juanes M, Guercio G, Marino R, Berensztein E, Warman DM, Ciaccio $M$ et al. Three novel IGF1R mutations in microcephalic patients with prenatal and postnatal growth impairment. Clin Endocrinol (Oxf) 2015; 82(5): 704-711. 


\title{
Резиме
}

\section{ТРЕТМАН СО ХОРМОН ЗА РАСТ КАЈ ДЕЦАТА РОДЕНИ МАЛИ ЗА ВОЗРАСТА}

\author{
Александра Јанчевска, Марина Крстевска-Константинова, Велибор Тасиќ, Зоран Гучев \\ Универзитетска клиника за детски болести, Медицински факултет, Скопје, Република Македонија
}

Вовед: Нарушувањето на растот е честа последица кај децата родени мали за гестациската возраст (СГА).

Пациенти и методи: Беа евалуирани постигнувањата во растот и серумските концентрации на ИГФ1 кај 32 ниски СГА родени деца лекувани со хормон за раст (ГХ) пред започнувањето и една година по започнувањето со третманот. Дополнително, го истражувавме егзон 2 на генот за ИГФ1 рецепторот како хотспот за можни генетски аберации во тој ген.

Резултати: Тестовите на питуитаната резерва беа во нормални граници кај сите 32 пациенти. Третманот со хормон за раст (XP) $(0,037 \mathrm{mg} / \mathrm{kg} /$ day $)$ беше започнат на средна возраст од $9,32 \pm$ 3,19 години. Брзината на раст беше годишно евалуирана и беше најдено постепено зголемување на средната вредност на В СДС од $-1,80$ СДС по првата година до - 0,03 СДС по шестата година од третманот. Измерените ИГФ1 серумски концентрации пред започнувањето со третманот беа соодветни за полот и возраста, додека во текот на третманот тие значајно пораснаа, одговарајќи на горната третина од нормалниот опсег: пред третманот ИГФ 1 СДС беше $-0,84 \pm 1,78$, а една година по започнување со третманот пораснаа и ИГФ1 СДС беше $0,94 \pm 2,23$. Со ПСР анализата не беа најдени генетски алтерации во егзон 2 на ИГФР1 генот.

Заклучоци: Прикажани се 32 СГА родени деца со низок раст, без дизморфични карактеристики, кои беа третирани со XР. Сите тие ја зголемија брзината на растењето и влегоа во нормалниот опсег на раст на своите табели за раст. Не се забележани несакани ефекти. Лекување со XР кај децата со СГА без генетски промени на IGF1R во егзонот 2 е ефикасен и безбеден во лекувањето на СГА деца со низок раст.

Клучни зборови: мали за гестациската возраст, низок раст, ИГФ1, ИГФ1 рецептор, третман со хормон за раст 